\title{
FDITORIAL \\ https://doi.org/10.30886/estima.v17.809_IN \\ Patient-centered enterostomal therapy as a shared management strategy and clinical decision
}

\section{Estomaterapia centrada no paciente como estratégia de gestão e decisão clínica compartilhada}
Estomaterapia centrada en el paciente como estrategia de manejo y decisión clínica compartida

Maria Angela Boccara de Paula ${ }^{1, *}$

ORCID ID

Paula MAB (D) https://orcid.org/0000-0002-7438-9595
HOW TO CITE

PaulaMAB.(2019)Patient-centeredenterostomal therapy as a shared management strategy and clinical decision. ESTIMA, Braz. J. Enterostomal Ther., 17: e2319. https://doi.org/10.30886/ estima.v17.809_IN

Care arises with the history of humanity, is the object of nursing work and has been studied by philosophers, historians and anthropologists, but it is nursing itself that produces more knowledge on the subject ${ }^{1}$.

Nurse specialists in enterostomal therapy develop their practice in the care of people with stomata, wounds and incontinence, using highly specialized techniques, procedures and care in order to ensure the excellence of the care they provide. But how to do this in a strategic and individualized way, valuing the bioethics principles of beneficence, nonmaleficence, justice and autonomy?

There are many aspects to be considered when the specific objective is patient-centered care. It is necessary to meet the demands of individuals and understand them as singular and plural beings that simultaneously represent the part and the whole ${ }^{2}$.

Therefore, respect for the values, preferences and needs of each person under our care must be considered. The recognition that each individual is unique demands an assistance plan that meets their specificities.

Meeting specific and unique demands of each person requires coordination and integration of care, also to reduce the feeling of vulnerability in patients. One of the ways to make this possible is through a shared decision, based on educational and informative actions, in which the health team provides essential elements for the patient and family to improve their knowledge about the health condition and possible treatments, so they can have elements to give their opinion and choose the most appropriate and comfortable decision for the person and family. In such a way that professionals and patients share the

1. Universidade de Taubaté - Departamento de Enfermagem e Nutrição e Programa de Mestrado em Desenvolvimento Humano - Taubaté (SP), Brazil. *Correspondence author: boccaradepaula@gmail.com

Received: Oct. 22, 2019 | Accepted: Nov. 13, 2019 
best available evidence when facing the task of making decisions, and thus patients and relatives are encouraged to compare options in order to achieve informed preferences.

Integrated care also intends to provide physical comfort to the assisted person, making the experience of hospitalization or treatment the best possible, considering feelings, demands, perceptions, preferences, meanings and especially the experiences of the patient himself.

Being at risk, hospitalized or performing diagnostic tests and treatments, even if in an ambulatory, produces insecurity, generates fears and anxiety, so it is essential that the health team seeks strategies to safely perform the so necessary emotional support, in order to minimize these feelings and provide security for total adherence to treatment.

Thus, for this involvement to be really possible, it is essential to coordinate and adapt care to the individual's needs, so it is not sufficient for professionals to have great mastery of the problem and determine the course to be taken in treatment. There is an utmost requirement to ensure that people are always treated with dignity, compassion and respect, to allow for active welcoming and listening, since it is also necessary to notice the health needs that are often omitted by patients. For this objective, it is important to create a favorable environment, both physical and relational ${ }^{3}$.

The reception requires from the professionals the incorporation of continuous discussions about their work process $^{4}$ and also allows to trigger reflections and changes in the organization of health services ${ }^{5}$, in which the listening and dialogue established with the reception allow the construction of solidarity meetings, opening possibilities to meet the health needs of people in a satisfactory way ${ }^{6}$.

It is important that professionals are able to engage in dialogue in order to involve the patient's support network, i.e., family members and close friends, since it is they who can more easily have access to the emotions, anxieties and needs of the person under care, since many professionals aspire to excellence in the diagnosis and treatment of diseases, but few aspire to this same standard of excellence in the diagnosis of what patients prefer or desire.

With these actions the patient gradually understands his clinical picture, therapeutic possibilities, prognosis and, thus, can take the front of his choices, in a conscious and well-informed way and, therefore, being part of the whole process that concerns himself.

Patient-centered care helps people acquire knowledge and develop the skills and confidence they need to manage and make informed decisions about their own health and healthcare effectively. Healthcare is often provided "for" people, not "with" them. In addition, there is difficulty in including patients in decisions and often their objectives are considered only from the perspective of specific clinical outcomes.

To routinely adopt person-centered care, it is necessary to promote fundamental changes in the way services are provided, in the roles of the people involved - not only health professionals, but also patients and relatives - and in the relationships between patients, family, and health teams and professionals. Therefore, it is necessary to create articulation mechanisms between the activities of the health team and the other sectors involved to ensure care.

Thus, a management challenge is established and consists of programming forms of participation and involvement of different agents in the health context, seeking to bring workers closer to the result of their professional practice, so that in fact there is integration between the professionals who manage the care and the health service. Care management emerges in organizations as a tendency to change the work process in this sector - starting from individual to a transdisciplinary work, reaffirming the need for responsibility, autonomy, and linking of teams of professionals to promote health.

It is necessary for the involved professionals to have technical, political and operational capacity to plan assistance, since care management comprises the set of actions designed to solve a problem and produce the necessary care. Professionals need to be prepared for this activity in all its dimensions, in order to understand their role, as well as to be able to follow the patients, demonstrating to them that they can and should act in favor of their own health, with actions for disease prevention and maintenance of their physical and mental health conditions ${ }^{7}$. 
Although it is not a simple process and it is considered that clinical practice and healthcare tangent the politicalinstitutional guidelines, it is known that person-centered care is already provided by a modest (though growing) number of services with very positive results.

Change requires effort, a collective effort, but it is certainly possible.

\section{REFERENCES}

1. Siewert JS, Rodrigues DB, Malfussi LBH, Andrade SR, Erdmann AL. Gestão do cuidado integral em enfermagem: reflexões sob a perspectiva do pensamento complexo. Rev Mineira Enf. 2017;21:1-5. https://doi.org/10.5935/1415-2762.20170057

2. Morin E. Os sete saberes necessários à educação do futuro. Tradução: CEF Silva, J Sawaya. São Paulo: Cortez; Brasília, DF: UNESCO, 2011.

3. Silva JLBV, Oliveira ABC, Oliveira AGM, Oliveira KD, Oliveira FMC, Alves MRR. A prática da integralidade na gestão do cuidado: relato de experiência. Rev Enferm UFPE on-line. 2017;11(2):792-7.

4. Damasceno RF, Sousa LPS, Ruas MFL, Brito PA, Silva EA, Silva JLS. O acolhimento no contexto da estratégia Saúde da família. J Health Sci Inst. 2012;30(1):37-40.

5. Moura GMSS, Magalhães AMM, Souza DB, Dall'Agnol CM. The social representations of the process of choosing leaders in the perspective of the nursing team. Rev Esc Enferm USP. 2012;46(5):1155-61. https://doi.org/10.1590/S0080-62342012000500017

6. Sá CMCP, Moura SG, Braga LAV, Dias MD, Ferreira Filha MO. Experiência da implantação do acolhimento em uma Unidade de Saúde da família. Rev Enferm UFPE on line. 2013;7(esp):5029-35.

7. Pires MRGM, Gottems LBD, Vasconcelos Filho JE, Silva KL, Gamarski R. Sistema de informação para a gestão do cuidado na rede de atenção domiciliar (SI GESCAD): Subsídio à coordenação e à continuidade assistencial no SUS. Ciênc Saúde Coletiva. 2015;20(6):1805-14. https://doi.org/10.1590/1413-81232015206.00152014 